\title{
EFFECT OF DIETARY SUPPLEMENTED COWPEA (Vigna unguiculata) HAY AS REPLACEMENT OF CONCENTRATE ON PERFORMANCE AND ECONOMIC EFFICIENCY OF ABERGELLE GOATS
}

\author{
Bewketu AMARE ${ }^{1 \otimes}$ and Ayalew GIRMAY2 \\ Sekota Dry Land Agriculture Research Center, P.o.box 62, Sekota, Ethiopia \\ Email: bewketa21@gmail.com; (1) ORCiD: 0000-0002-5739-7438 \\ supporting Information
}

\begin{abstract}
The study were conducted at Sekota district using twenty four yearling male Aberegelle goats for 100 days to evaluate the effect of substitution of concentrate mix with cowpea hay on biological and economic benefits. The treatments were natural grass hay alone (T1) and supplemented with $100 \%$ concentrate mix $\left(T_{2}\right)$, 75: $25 \%\left(T_{3}\right), 50: 50 \%\left(T_{4}\right), 25: 75 \%\left(T_{5}\right)$ concentrate mix: cowpea hay and $100 \%$ cowpea hay $\left(T_{6}\right)$ per head per day. Randomized complete block design with six treatments and five replications was used. The crude protein (CP) content of grass hay, concentrate mix and cowpea hay were $6.80,16.30$ and $19.62 \%$, respectively. Daily hay dry matter $(D M)$ intake of the control was significantly higher $(P<0.05)$ than other treatments. Apparent $D M$, organic matter (OM), acid detergent fiber (ADF), neutral detergent fiber (NDF), CP digestibility and body weight change of supplemented treatments were significant $(P<0.001)$ as compared to the control, however there were no significant differences in intake, digestibility, linear body measurement and growth performance of goats fed different proportion of concentrate and cowpea hay. However, sole cowpea hay supplementation performs better in terms of net return and farmers' preference. Therefore, supplementation of sole cowpea hay would be both biologically, economically and socially acceptable level for Abergelle goats bred.
\end{abstract}

Keywords: Cowpea, Digestibility, Feed intake, Ruminant.

\section{INTRODUCTION}

In Ethiopia feeding of ruminant depend on crop residues and poor quality hay. As a result, the digestibility and intake of these feeds are low which results in poor performance (Mekuriaw and Asmare, 2018; Wamatu et al., 2019). Despite the potential economic benefits, cereal grain and concentrate supplementation to low-quality feeds is unaffordable by smallholder farmers in addition to scarcity and its use as human food. Therefore, there is a need to look for protein sources that farmers could get from their own farm with minimum cost. One potential way could be through the use of fodder trees, shrub and herbaceous legumes. One of such fodder legumes is cowpea which is relatively drought-resistant plant (Paul et al., 2020). Sekota dry land research center had recommended two varieties of cowpea which have potential to produce high biomass ranging from1.8 to 2.1 DM t/ha (SDARC, 2008). And most of the farmers grown local cultivar for seed production, biomass during dry season and used the haulm for feeding selected animals such as ill, lactating and castrated animals. This illustrates cowpea is an excellent source of protein ranging from $19.5-26 \%$ which could be a substitute for more expensive concentrates (Owolabi et al., 2012).

However, in Ethiopia information on feeding value of cowpea hay in relation to goat performance is scanty especially as a substitute to conventional protein supplement. Therefore, the objective of the study was to evaluate the effect of substitution of concentrate mixture with cowpea hay on feed intake, digestibility and weight change of Abergelle goats and to determine the economic feasibility.

\section{MATERIALS AND METHODS}

\section{Description of the study area}

The study was conducted in Sekota district, Ethiopia. It is located between $12^{\circ} 23^{\prime}$ and $13^{\circ} 16^{\prime}$ north and $38^{\circ} 44^{\prime}$ and $39^{\circ} 21^{\prime}$ east (CSA, 2014). The altitude ranges from 1340-2200 meters above sea level (WZAD, 1995). Annual rainfall ranges between 350-650 $\mathrm{mm}$ (AMAREW, 2006).

\section{Feed intake, body weight and linear body measurement}

Natural pasture grass hay was purchased from farmers and hand chopped to a size of about 1-10 cm. Cowpea were planted in Sekota research center farm and harvested at $50 \%$ blooming. The concentrate mixture was composed of $70 \%$ wheat bran and $30 \%$ Noug seed cake. The feed were offered in two equal proportions at 0800 and 1600 hour. The feed 
was formulated based on metabolizable energy and crude protein requirements for maintenance and growth of Aberegelle goat (Bewketu Amare et al., 2015) weighting 15-20 kg and with expected 70g/day weight gain. Grass hay was offered ad libitum allowing $20 \%$ refusal. Water and salt licks had available free choice. Daily feed offers and refusals per goat were collected and weighted to determine daily feed intake. Samples of feed offered and refused were collected, bulked and sub-samples were taken after thoroughly mixing for determination of nutrient composition. Live body weights of goat were measured every 10 days after overnight fasting. Average daily weight gain was calculated as the difference between final and initial weight divided by 90 days. Metabolizable energy intake were estimated as follows: $\mathrm{ME}(\mathrm{MJ} / \mathrm{kg})=$ 0.0157 * digestible organic matter intake (AFRC, 1993): Microbial N production=1.34* Metabolizable energy intake (ARC, 1984). Linear body measurements were measured using tape meter (Deboer et al., 1974). The total gain was calculated as the difference of initial and final measurement.

\section{Experimental animal's management and treatments}

Twenty four intact yearling male Aberegelle goats were purchased from local market. Age of goat was determined by looking at their dentition and information gathered from the owners. All goats were de-wormed, injected against internal and external parasite as well as vaccinated against disease. Randomized Complete Block Design (RCBD) was used. Treatments were a basal diet of natural pasture grass hay alone $\left(\mathrm{T}_{1}\right)$ and supplemented with $100 \%$ concentrate mix $\left(T_{2}\right), 75: 25 \%\left(T_{3}\right), 50: 50 \%\left(T_{4}\right), 25: 75 \%\left(T_{5}\right)$ concentrate mix: cowpea hay and 100\% cowpea hay $\left(T_{6}\right)$ per head per day.

\section{Digestibility trial}

Digestibility trial was conducted after the end of feeding trial. All goats were fitted with fecal collection bags for five days of adaptation period before the resumption of actual collection of feces for nine consecutive days. The daily feces output of each goats were collected and weighted. After thorough mixing, $30 \%$ of the daily fecal excretion of each goat were sampled and stored at $-20{ }^{\circ} \mathrm{C}$. After nine days, feces were thawed and sub-sample from each plastic bag and pooled per goat. Apparent digestibility of nutrients was calculated as the proportion of the difference between nutrient consumed and nutrient in feces to nutrient consumed.

\section{Chemical analysis}

Samples of feed offer, refusal and feces were dried in an oven at $60^{\circ} \mathrm{C}$ for 72 hours and ground to pass through $1 \mathrm{~mm}$ sieve. All samples were analyzed for DM, ash, OM and $\mathrm{N}$ contents (AOAC, 1995). Neutral detergent fiber (NDF), acid detergent fiber (ADF) and acid detergent lignin (ADL) contents were analyzed according to the procedure of VanSoest and Robertson (1985). Hemicelluloses, cellulose and soluble matter were calculated as NDF minus ADF, ADF minus ADL and 100 minus NDF, respectively.

\section{Economic analysis and farmers assessment of the feeding trial}

Partial budget analysis was performed using the procedure of Upton (1979). In the tradition of Sekota farmers, natural pasture grass and cowpea hay were sold with local name of Mewogeya and Shekeme, respectively. They sold a single Mewogeya and Shekeme with 80 and 45 birr. A single Mewogeya and Shekeme weights on average of $70 \mathrm{~kg}$ and $25 \mathrm{~kg}$ then after translate in to selling price of hay per kilogram, respectively. The buying and selling price of each goat was determined by inviting well experienced goat dealers who know market price of different size of goat in the area. The feed, labor, load and unload, transport and medicament cost were considered as total variable costs. The net return was calculated by subtracting total variable cost (TVC) from total return (TR). The marginal rate of return (MRR) measures the increase in net return $(\Delta N R)$ associated with each additional unit of expenditure $(\Delta T V C)$. The gross margin analysis was also used to examine the relative contribution of price, weight and their interaction from the gross return (Baur et al., 1989). Sensitivity analysis was also done to capture the likely change in prices of input (feed) and fattened goats. In Ethiopia, the price of animal feed for the last five years has shown an average of $20 \%$ increment (USAID, 2013). Thus, sensitivity analysis was hypothesized for $20 \%$ increase in feed cost and $20 \%$ decrease in selling price of goats. After finishing the feeding trial, a field day was organized and farmer perceptions toward the technology were assessed.

\section{Statistical analysis}

Data on feed intake, digestibility, growth and economic parameters were analyzed using the General Linear Model (GLM) procedure of SAS (2003). Mean values were compared by Duncan's Multiple Range Test (Duncan, 1955). The model, $Y_{i j}=\mu+T_{i}+B_{j}+e_{i j}$ was used, where: $Y_{i j}=$ Individual observation; $\mu=$ Overall mean; $T_{i}=$ Treatment effect; $B_{j}=$ Block effect and $e_{i j}=$ Random error

\section{RESULT AND DISCUSSIONS}

\section{Chemical composition of treatment feeds}

Except natural pasture grass hay, all other ingredients had medium and high CP contents (Table 1). The CP content of cowpea hay in the current experiment is within the range of 19.4 to $26 \%$ reported by Alexander et al. (2007) and 18.7820.22\% for different level of fertilizer supplemented cowpea forage (Hasan et al., 2010). The CP content of grass hay in 
this experiment is higher than 5.15\% CP (Ajebu Nurfeta., 2010), respectively. However, it was lower than 7.5-10.9\% CP of harvested native pasture hay at 90 and 170 days from Andasa area (Yihalem et al., 2004). This difference in nutrient content of hay could be due to variation plant species, sampling, and method of preparation, climate, plant fraction and stage of maturity at harvesting.

Table 1 - Chemical composition of treatment feeds

\begin{tabular}{|c|c|c|c|c|c|c|c|c|c|c|}
\hline \multirow{2}{*}{ Type of feed } & \multirow{2}{*}{ DM \% } & \multicolumn{9}{|c|}{ Nutrient (\% DM) } \\
\hline & & Ash & OM & CP & NDF & ADF & ADL & HC & C & SM \\
\hline Natural grass hay & 90.00 & 10.00 & 90.00 & 6.80 & 75.00 & 44.44 & 19.99 & 30.56 & 24.45 & 25.00 \\
\hline Cowpea hay & 91.00 & 10.00 & 90.00 & 19.62 & 57.77 & 31.11 & 15.50 & 26.66 & 15.61 & 42.23 \\
\hline Wheat bran & 89.00 & 14.00 & 86.00 & 11.88 & 68.88 & 13.33 & 6.60 & 55.55 & 6.73 & 31.12 \\
\hline Noug seed cake & 88.00 & 10.00 & 90.00 & 26.62 & 42.22 & 33.33 & 13.30 & 8.89 & 20.03 & 57.78 \\
\hline Concentrate mix & 88.70 & 12.80 & 87.20 & 16.30 & 60.88 & 19.33 & 8.61 & 41.55 & 10.72 & 39.12 \\
\hline \multicolumn{11}{|l|}{ Refusal hay } \\
\hline $\mathrm{T}_{1}$ & 90.00 & 8.75 & 91.25 & 6.56 & 76.11 & 53.33 & 25.27 & 22.78 & 28.06 & 23.89 \\
\hline$T_{2}$ & 90.00 & 8.50 & 91.50 & 6.90 & 73.89 & 52.78 & 24.44 & 21.11 & 28.34 & 26.12 \\
\hline$T_{3}$ & 90.00 & 8.50 & 91.50 & 6.52 & 74.44 & 52.22 & 30.83 & 22.22 & 21.39 & 25.56 \\
\hline$T_{4}$ & 90.00 & 8.00 & 92.00 & 6.58 & 71.85 & 52.59 & 29.25 & 19.26 & 23.34 & 28.15 \\
\hline$T_{5}$ & 90.00 & 7.75 & 92.25 & 8.09 & 74.99 & 56.94 & 28.05 & 18.06 & 28.89 & 25.00 \\
\hline$T_{6}$ & 90.00 & 8.50 & 91.50 & 7.07 & 73.89 & 56.11 & 32.77 & 17.78 & 23.34 & 26.12 \\
\hline
\end{tabular}

$\mathrm{DM}=$ dry matter; $\mathrm{OM}=$ organic matter; $\mathrm{CP}=$ crude protein; NDF=neutral detergent fiber; $\mathrm{ADF}=$ acid detergent fiber; $\mathrm{ADL}=$ acid detergent lignin; $\mathrm{HC}=$ hemicelluloses; $\mathrm{C}=$ cellulose; $\mathrm{SM}=$ soluble matter. $\mathrm{T}_{1}=$ natural grass hay alone; $\mathrm{T}_{2}=$ natural grass hay $+0 \%$ cowpea hay: $100 \%$ concentrate mix:; $\mathrm{T}_{3}=$ natural grass hay $+25 \%$ cowpea hay: $\mathbf{7 5} \%$ concentrate mix; $\mathrm{T}_{4}=$ natural grass hay $+50 \%$ cowpea hay: $50 \%$ concentrate mix; $\mathrm{T}_{5}=$ natural grass hay $+75 \%$ cowpea hay: $25 \%$ concentrate mix; $\mathrm{T}_{6}=$ natural grass hay $+100 \%$ cowpea hay: $0 \%$ concentrate mix

\section{Dry matter and nutrients intake}

Supplementation resulted in significantly greater DM, OM, CP and ME intake compared to the control however, statistically similar among supplemented treatments (Table 2). The non-significant difference in NDF and ADF could be due to the higher fiber content of the basal diet in the control. Similarity, substitution rate obliviously due to similar intake of basal diet among supplemented treatments and substituting concentrate mixture with cowpea hay had no negative effect on basal diet intake. Similarly, Patra et al. (2006) observed does fed concentrate containing soybean and leaf mixtures had similar DM, OM and CP intake among treatments with basal diet of wheat straw. On the other hand, Foster et al. (2009) found reduced DM and OM intakes with increasing levels of pigeon pea hay as a supplement to grass hay compared with the control. Moreover, the total DM intake per body weight in all treatments was within the range of 2-6\% recommended for goats (ARC, 1980). The higher intake of hay for the control might be due to the deficiency of nutrients in the hay and is an attempt for goat trying to satisfy their nutrient requirement through relatively more hay intake. All treatments were above the minimum CP and energy requirement for maintenance and rumen function of $33 \mathrm{~g} / \mathrm{day} \mathrm{CP}$ and $3.31 \mathrm{MJ} /$ day ME, respectively for $15 \mathrm{~kg}$ goats (Kearl, 1982). The microbial nitrogen production in the supplemented group was greater than 10.2-10.9 g/day of Adilo sheep (Ajebu Nurfeta et al., 2013).

Table 2 - Dry matter and nutrients intake of Abergelle goat fed on natural pasture grass hay and supplemented with different proportion of cowpea hay and concentrate mix

\begin{tabular}{|c|c|c|c|c|c|c|c|c|}
\hline \multirow{2}{*}{ Intake (g/day) } & \multicolumn{8}{|c|}{ Treatments } \\
\hline & $T_{1}$ & $T_{2}$ & $T_{3}$ & $T_{4}$ & $T_{5}$ & T6 & SEM & P-value \\
\hline Hay DM & $885.07^{a}$ & $769.51^{b}$ & $692.38^{b}$ & $740.46^{b}$ & $710.75^{b}$ & $765.97^{b}$ & 20.38 & 0.0001 \\
\hline Cowpea hay DM & - & - & $93.71^{d}$ & $178.64^{c}$ & $276.72^{b}$ & $356.54^{a}$ & 29.21 & 0.0001 \\
\hline Concentrate mix DM & - & $295.42^{\mathrm{a}}$ & $225.00^{b}$ & $148.37^{c}$ & $75.00^{d}$ & - & 24.05 & 0.0001 \\
\hline Total DM & $885.07^{c}$ & $1064.93^{\mathrm{ab}}$ & $1011.09^{b}$ & $1067.46^{\mathrm{ab}}$ & $1062.47^{\mathrm{ab}}$ & $1122.52^{a}$ & 22.39 & 0.0001 \\
\hline Total OM & $796.56^{c}$ & $950.17^{\mathrm{ab}}$ & $903.68^{b}$ & $956.56^{a b}$ & $954.13^{\mathrm{ab}}$ & $1010.27^{a}$ & 20.07 & 0.0001 \\
\hline Total CP & $60.19^{e}$ & $100.48^{d}$ & $102.15^{\mathrm{cd}}$ & $109.59^{b c}$ & $114.85^{\mathrm{ab}}$ & $122.04^{a}$ & 4.46 & 0.0001 \\
\hline Total NDF & $663.80^{b}$ & $756.99^{a}$ & $710.41^{\mathrm{ab}}$ & $748.87^{a}$ & $738.59^{\mathrm{ab}}$ & $780.46^{a}$ & 14.12 & 0.001 \\
\hline Total ADF & $393.32^{b}$ & $399.08^{b}$ & $380.34^{b}$ & $413.31^{a b}$ & $416.44^{\mathrm{ab}}$ & $451.32^{a}$ & 8.41 & 0.001 \\
\hline EMN & $11.26^{b}$ & $15.69^{a}$ & $14.89^{a}$ & $15.23^{a}$ & $15.59^{a}$ & $15.76^{a}$ & 0.39 & 0.0001 \\
\hline EME (MJ/day) & $8.40^{b}$ & $11.72^{\mathrm{a}}$ & $11.12^{\mathrm{a}}$ & $11.36^{a}$ & $11.63^{a}$ & $11.76^{a}$ & 0.29 & 0.0001 \\
\hline Substitution rate & - & $0.39 a$ & $0.60^{a}$ & $0.44^{a}$ & $0.49^{a}$ & $0.34^{a}$ & 0.05 & 0.01 \\
\hline$\%$ live body weight & $5.96^{a}$ & $5.18^{b}$ & $4.89^{\mathrm{b}}$ & $5.45^{\mathrm{ab}}$ & $5.26^{b}$ & $5.47^{\mathrm{ab}}$ & 0.11 & 0.01 \\
\hline
\end{tabular}




\section{Apparent digestibility}

Apparent DM, OM, ADF, NDF and CP digestibility of supplemented treatments were significant $(P<0.001)$ as compared to control group, however similar among supplemented treatments. This might suggest that supplementation of cowpea and concentrate mixture might have favored comparable and high rumen fermentation and increased production of rumen biomass (McDonald et al., 2002). The DM digestibility values obtained in supplemented treatments fell within the range of $70 \%$ to $79 \%$ deemed as indicative of high digestible level (Lee, 2008), and that of control was found within the range of $60 \%$ to $65 \%$ regarded as moderately acceptable digestibility for average animal performance (Devendra and McLeory, 1982).

Table 3 - Apparent digestibility of nutrients in Abergelle goat fed on natural pasture grass hay and supplemented with different proportion of cowpea hay and concentrate mix

\begin{tabular}{l|c|c|c|c|c|c|c|c}
\multirow{2}{*}{ Digestibility (\%) } & \multicolumn{9}{c}{ Treatments } \\
\cline { 2 - 9 } & $\mathbf{T}_{\mathbf{1}}$ & $\mathbf{T}_{\mathbf{2}}$ & $\mathbf{T}_{\mathbf{3}}$ & $\mathbf{T}_{\mathbf{4}}$ & $\mathbf{T}_{\mathbf{5}}$ & $\mathbf{T}_{\mathbf{6}}$ & SEM & P-value \\
\hline DM & $65.58^{\mathrm{b}}$ & $77.85^{\mathrm{a}}$ & $77.93^{\mathrm{a}}$ & $75.05^{\mathrm{a}}$ & $77.07^{\mathrm{a}}$ & $73.21^{\mathrm{a}}$ & 1.26 & 0.0001 \\
OM & $67.31^{\mathrm{b}}$ & $78.68^{\mathrm{a}}$ & $78.56^{\mathrm{a}}$ & $75.80^{\mathrm{a}}$ & $77.74^{\mathrm{a}}$ & $74.36^{\mathrm{a}}$ & 1.18 & 0.0001 \\
CP & $50.66^{\mathrm{b}}$ & $76.19^{\mathrm{a}}$ & $74.43^{\mathrm{a}}$ & $72.07^{\mathrm{a}}$ & $73.09^{\mathrm{a}}$ & $70.42^{\mathrm{a}}$ & 2.07 & 0.0001 \\
NDF & $63.68^{\mathrm{c}}$ & $76.48^{\mathrm{ab}}$ & $77.53^{\mathrm{a}}$ & $70.42^{\mathrm{abc}}$ & $74.29^{\mathrm{ab}}$ & $69.69^{\mathrm{bc}}$ & 1.47 & 0.001 \\
ADF & $57.50^{\mathrm{b}}$ & $68.01^{\mathrm{a}}$ & $69.77^{\mathrm{a}}$ & $62.45^{\mathrm{ab}}$ & $69.44^{\mathrm{a}}$ & $62.71^{\mathrm{ab}}$ & 1.54 & 0.01
\end{tabular}

a-cMeans within a row not bearing a common superscript are significantly different; SEM= standard error of mean; DM=dry matter; OM= organic matter; $C P=$ crude protein; NDF=neutral detergent fiber; $A D F=a c i d$ detergent fiber; $T_{1}=$ natural grass hay alone; $T_{2}=$ natural grass hay $+0 \%$ cowpea hay: $100 \%$ concentrate $\mathrm{mix} ; \mathrm{T}_{3}=$ ad libitum natural pasture grass hay $+25 \%$ cowpea hay: $75 \%$ concentrate mix; $T_{4}=$ natural grass hay $+50 \%$ cowpea hay: $50 \%$ concentrate mix; $\mathrm{T}_{5}=$ natural grass hay $+\mathbf{7 5} \%$ cowpea hay: $25 \%$ concentrate mix; $\mathrm{T}_{6}=$ natural grass hay + $100 \%$ cowpea hay: $0 \%$ concentrate mix.

\section{Body weight change}

Supplementation significantly improved $(P<0.001)$ final weight, weight gain and feed conversion efficiency as compared to the control, however statistically similar among supplemented treatments. Despite the CP and ME intake of the control used in this experiment was above the minimum nutrient requirement for maintenance of goats (Kearl, 1982), goats were unable to maintain body weight fed hay alone. This might be presumably have due to high fiber content, low digestibility, higher minimum nutrient requirement for maintenance of this breed and higher urinary loss. Moreover, the similarity in body weight change among supplemented treatments reflects that the supplements are comparable in their nutrient supply. Similar weight gain was also reported when cotton seed cake substituted Leucaena leucocephala at varying levels (Ndemanisho et al., 1998). However, forage to concentrate ratio was reported to affect average daily gain in kids where increasing the concentrate portion (Haddad, 2005). Furthermore, Karachi and Zengo (1998) and Keba (2009) reported increased body weight gain by increasing the amount of pigeon pea leaves which is not consistent with the current experiment. Generally, cowpea hay can be comparable supplementary value as sole or mixture with concentrate and provide similar performance as compared with concentrate mix. This is important in the areas where concentrate is not available especially for smallholder farmers.

Table 4 - Body weight change and feed conversion of Abergelle goat fed on natural pasture grass hay and supplemented with different proportion of cowpea hay and concentrate mix

\begin{tabular}{|c|c|c|c|c|c|c|c|c|}
\hline \multirow{2}{*}{ Digestibility (\%) } & \multicolumn{8}{|c|}{ Treatments } \\
\hline & $\mathbf{T}_{\mathbf{1}}$ & $T_{2}$ & $T_{3}$ & $\mathbf{T}_{\mathbf{4}}$ & $T_{5}$ & $T_{6}$ & SEM & P-value \\
\hline Initial body weight & 16.20 & 16.45 & 15.90 & 14.60 & 15.85 & 15.90 & 0.37 & 0.06 \\
\hline Final body weight & $14.85^{b}$ & $20.70^{a}$ & $20.80^{a}$ & $19.57^{a}$ & $20.20^{a}$ & $20.75^{a}$ & 0.59 & 0.0001 \\
\hline Total weight gain & $-1.35^{b}$ & $4.25^{\mathrm{a}}$ & $4.90^{\mathrm{a}}$ & $4.97^{a}$ & $4.35^{a}$ & $4.85^{a}$ & 0.51 & 0.0001 \\
\hline Daily gain (g/day) & $-15.00^{b}$ & $47.22^{a}$ & $54.44^{a}$ & $55.19^{a}$ & $48.33^{a}$ & $53.89 a$ & 5.64 & 0.0001 \\
\hline FCE & $-0.017^{b}$ & $0.044^{a}$ & $0.054^{a}$ & $0.052^{a}$ & $0.045^{a}$ & $0.049^{a}$ & 0.01 & 0.0001 \\
\hline
\end{tabular}

\section{Linear body measurement}

Most traits of supplemented goats were higher $(P<0.05)$ linear body measurement than control (Table 6). This could be due to supplementation caused muscle and fat cover accumulation around the vertebrae, in the loin and leg region as well as skeletal development (Tesfa et al., 2013). The average values for final HG and BL of current study were comparable with Abergelle goats under on farm condition (Halima Hassen et al., 2012).

\section{Economic analysis of the feeding trial}

Even though the analysis revealed that feeding with supplementation in the trial was profitable, goats fed entirely sole hay $\left(\mathrm{T}_{1}\right)$ lost 22.33 ETB which was in line with Jemberu et al. (2010) for Simada sheep (-30 ETB/sheep). The reasons 
for the negative net return might be due to relatively lower body weight, poor body condition and conformation as a result of lower nutrient intake. There is only significant difference when the level of cowpea hay was above $50 \%$ of the supplement as compared with the control. Moreover, the higher net return and rate return in $\mathrm{T}_{6}$ was due to lower cost of feed per live weight gain as a result of availability of cowpea hay in the area. In addition to weight gain, time of purchasing feeds, time of buying and selling price of goats were a major contributor for improving profitability. Generally, the result of this study suggested that the importance of formulating cheap feed source that can substitute expensive industrial byproducts and supplementation of natural grass hay with sole cowpea hay was economically beneficial than sole concentrate mix or mixture with cowpea hay for Abergelle goats.

Table 5 - Linear body measurement of Abergelle goat fed on natural pasture grass hay and supplemented with different proportion of cowpea hay and concentrate mix

\begin{tabular}{|c|c|c|c|c|c|c|c|c|}
\hline \multirow{2}{*}{ Parameters } & \multicolumn{8}{|c|}{ Treatments } \\
\hline & $T_{1}$ & $T_{2}$ & $T_{3}$ & $\mathbf{T}_{4}$ & $T_{5}$ & $T_{6}$ & SEM & P-value \\
\hline Final HG (cm) & $57.25^{b}$ & $64.13^{a}$ & $64.63^{a}$ & $63.67^{a}$ & $64.75^{a}$ & $63.75^{a}$ & 0.68 & 0.0001 \\
\hline Final $B L(c m)$ & $56.75^{c}$ & $62.75^{\mathrm{ab}}$ & $62.75^{\mathrm{ab}}$ & $62.67^{a b}$ & $63.88^{a}$ & $59.88^{b}$ & 0.75 & 0.0001 \\
\hline Final HW (cm) & $56.63^{c}$ & $64.00^{\mathrm{ab}}$ & $64.38^{\mathrm{ab}}$ & $61.17^{b}$ & $64.88^{a}$ & $62.75^{\mathrm{ab}}$ & 0.77 & 0.0001 \\
\hline Final PW (cm) & $9.00^{b}$ & $11.25^{a}$ & $11.50^{a}$ & $11.83^{a}$ & $12.00^{a}$ & $11.75^{a}$ & 0.31 & 0.01 \\
\hline Final CW (cm) & $12.50^{b}$ & $14.50^{a}$ & $14.38^{a}$ & $13.83^{a b}$ & $13.75^{\mathrm{ab}}$ & $13.75^{\mathrm{ab}}$ & 0.22 & 0.06 \\
\hline Final CD (cm) & $19.81^{b}$ & $22.19 a$ & $22.36^{a}$ & $22.03^{a}$ & $22.40^{a}$ & $22.06^{a}$ & 0.24 & 0.0001 \\
\hline Final BV $\left(\mathrm{cm}^{3}\right)$ & $12.08^{b}$ & $18.34^{a}$ & $18.66^{a}$ & $17.32^{a}$ & $18.70^{a}$ & $17.78^{a}$ & 0.63 & 0.001 \\
\hline Total HG gain $(\mathrm{cm})$ & $0.00^{b}$ & $6.88^{a}$ & $7.38^{a}$ & $6.00^{a}$ & $7.50^{a}$ & $6.50^{a}$ & 0.68 & 0.0001 \\
\hline Total BL gain $(\mathrm{cm})$ & $0.00^{c}$ & $6.00^{a b}$ & $6.00 a^{b}$ & $7.67^{a}$ & $7.13^{a}$ & $3.13^{b}$ & 0.81 & 0.0001 \\
\hline Total HW gain $(\mathrm{cm})$ & $0.00^{c}$ & $7.38^{\mathrm{ab}}$ & $7.75^{\mathrm{ab}}$ & $4.67^{b}$ & $8.25^{a}$ & $6.13^{a b}$ & 0.78 & 0.0001 \\
\hline Total PW gain $(\mathrm{cm})$ & $0.00^{b}$ & $2.25^{a}$ & $2.50^{a}$ & $2.50^{a}$ & $3.00^{a}$ & $2.75^{a}$ & 0.35 & 0.01 \\
\hline Total CW gain $(\mathrm{cm})$ & $0.00^{b}$ & $2.00^{a}$ & $1.88^{a}$ & $1.17^{\mathrm{ab}}$ & $1.25^{\mathrm{ab}}$ & $1.25^{\mathrm{ab}}$ & 0.25 & 0.01 \\
\hline Total CD gain $(\mathrm{cm})$ & $0.00^{b}$ & $2.38^{a}$ & $2.55^{a}$ & $2.08^{a}$ & $2.59^{a}$ & $2.25^{a}$ & 0.24 & 0.0001 \\
\hline Total BV gain $\left(\mathrm{cm}^{3}\right)$ & $0.00^{b}$ & $6.26^{a}$ & $6.59^{a}$ & $4.90^{a}$ & $6.63^{a}$ & $5.70^{a}$ & 0.65 & 0.001 \\
\hline
\end{tabular}

Table 6 - Economic analysis of the feeding trial Abergelle goat fed on natural pasture grass hay and supplemented with different proportion of cowpea hay and concentrate mix

\begin{tabular}{|c|c|c|c|c|c|c|c|c|}
\hline \multirow{2}{*}{ Parameters (birr) } & \multicolumn{8}{|c|}{ Treatments } \\
\hline & $T_{1}$ & $T_{2}$ & $T_{3}$ & $\mathbf{T}_{4}$ & $T_{5}$ & $T_{6}$ & SEM & P-value \\
\hline Grass hay cost & $42.98^{a}$ & $38.13^{b}$ & $33.62^{b}$ & $35.96^{b}$ & $33.81^{b}$ & $37.19^{b}$ & 1.08 & 0.001 \\
\hline Cowpea hay cost & - & - & $11.44^{\mathrm{d}}$ & $21.79^{c}$ & $33.91^{b}$ & $43.51^{\mathrm{a}}$ & 3.74 & 0.0001 \\
\hline Concentrate mix cost & - & $67.61^{\mathrm{a}}$ & $51.37^{b}$ & $33.87^{c}$ & $17.12^{\mathrm{d}}$ & - & 5.69 & 0.0001 \\
\hline Feed cost $(1+2+3)$ & $42.98^{d}$ & $105.75^{a}$ & $96.42^{b}$ & $91.63^{b}$ & $84.85^{c}$ & $80.71^{c}$ & 4.69 & 0.0001 \\
\hline Feed loan and unload & $8.59 c$ & $10.63^{\mathrm{ab}}$ & $9.96^{b}$ & $10.51^{\mathrm{ab}}$ & $10.35^{\mathrm{ab}}$ & $11.06^{a}$ & 0.25 & 0.0001 \\
\hline Feed transport & $17.19 \mathrm{e}$ & $69.34^{a}$ & $54.54^{b}$ & $41.48^{c}$ & $27.22^{d}$ & $14.88^{f}$ & 4.44 & 0.0001 \\
\hline Total feed cost $(4+5+6)$ & $68.77^{f}$ & $185.72^{a}$ & $160.93^{b}$ & $143.62^{c}$ & $122.42^{d}$ & $106.65^{e}$ & 8.69 & 0.0001 \\
\hline Labor & 58.33 & 58.33 & 58.33 & 58.33 & 58.33 & 58.33 & 0.00 & 0.06 \\
\hline Medicament cost & 3.24 & 2.36 & 2.36 & 2.36 & 2.36 & 2.36 & 0.17 & 0.06 \\
\hline TVC $(7+8+9)$ & $130.33^{f}$ & $246.41^{a}$ & $221.62^{b}$ & $204.31^{c}$ & $183.1^{\mathrm{d}}$ & $167.34^{\mathrm{e}}$ & 8.63 & 0.0001 \\
\hline Initial goat purchase & 337.50 & 382.22 & 369.17 & 323.33 & 351.11 & 373.33 & 13.40 & 0.06 \\
\hline Total cost $(10+11)$ & $467.83^{c}$ & $628.63^{a}$ & $590.78^{\mathrm{ab}}$ & $527.65^{\mathrm{bc}}$ & $534.22^{b}$ & $540.67^{b}$ & 17.45 & 0.0001 \\
\hline Selling price & $445.50^{b}$ & $652.93^{a}$ & $635.35^{a}$ & $593.97^{a}$ & $602.87^{a}$ & $634.05^{\mathrm{a}}$ & 21.39 & 0.0001 \\
\hline Net return & $-22.33^{b}$ & $24.30^{a b}$ & $44.57^{a b}$ & $66.32^{a}$ & $68.65^{a}$ & $93.38^{a}$ & 12.46 & 0.01 \\
\hline AFRR (\%) & $-19.04^{b}$ & $14.71^{\mathrm{ab}}$ & $33.21^{\mathrm{ab}}$ & $53.17^{a}$ & $53.67^{a}$ & $73.24^{a}$ & 9.93 & 0.01 \\
\hline MRR from control & - & 0.22 & 0.73 & 1.16 & 1.72 & 3.13 & - & - \\
\hline Marginal rate of return & - & 0.22 & -0.16 & -1.09 & -0.25 & -1.57 & - & - \\
\hline
\end{tabular}




\section{Different components of the gross margin}

The contribution of weight and price change for gross return is described in the Table 7. The current result of gross margin as percentages of financial return indicates that weight gain, as a whole, accounted for $55.46 \%$ of the gross margin while price changes and the interactions accounted for 26.06 and $18.48 \%$, respectively. This suggests that weight change over the feeding periods relatively played an important role in the determination of profitability

\section{Sensitivity analysis}

The sensitivity analysis of the current result is done in Table 8. Relatively speaking, the analysis indicated that profitability was highly affected by changes in selling price of goat. Generally, $\mathrm{T}_{6}$ was better to resist the fluctuation of the enterprise.

\begin{tabular}{|c|c|c|c|}
\hline Treatments & Price & Weight & Interaction \\
\hline $\mathrm{T}_{1}$ & 53.60 & 32.58 & 13.82 \\
\hline $\mathrm{T}_{2}$ & 19.12 & 61.76 & 19.12 \\
\hline$T_{3}$ & 19.42 & 61.15 & 19.42 \\
\hline$T_{4}$ & 21.26 & 57.48 & 21.26 \\
\hline$T_{5}$ & 19.44 & 61.11 & 19.45 \\
\hline$T_{6}$ & 18.92 & 62.17 & 18.96 \\
\hline Mean & 26.06 & 55.46 & 18.48 \\
\hline SEM & 6.03 & 4.75 & 1.90 \\
\hline $\mathbf{P}$ & 0.06 & 0.06 & 0.06 \\
\hline
\end{tabular}

Table 8 - Sensitivity analysis of the feeding trial in Abergelle goat fed on natural pasture grass hay and supplemented with different proportion of cowpea hay and concentrate mix

\begin{tabular}{|c|c|c|c|c|c|c|c|c|}
\hline \multirow{2}{*}{ Parameters (birr) } & \multicolumn{8}{|c|}{ Treatments } \\
\hline & $T_{1}$ & $T_{2}$ & $T_{3}$ & $\mathbf{T}_{4}$ & $T_{5}$ & $T_{6}$ & SEM & P-value \\
\hline NRo & $-22.33^{b}$ & $24.30^{\mathrm{ab}}$ & $44.57^{a b}$ & $66.32^{a}$ & $68.65^{a}$ & $93.38^{a}$ & 12.46 & 0.01 \\
\hline $\mathrm{NR}_{1}$ & $-30.93^{b}$ & $3.15^{\mathrm{ab}}$ & $25.28^{a b}$ & $48.00^{a}$ & $51.68^{a}$ & $77.24^{a}$ & 12.13 & 0.01 \\
\hline $\mathrm{NR}_{2}$ & $-111.43^{b}$ & $-106.29 b$ & $-82.50^{a b}$ & $-52.47 a b$ & $-51.93^{a b}$ & $-33.43^{a}$ & 10.58 & 0.01 \\
\hline $\mathrm{NR}_{3}$ & $-120.03^{a b}$ & $-127.43^{b}$ & $-101.79 a b$ & $-70.80^{a b}$ & $-68.89 a b$ & $-49.57^{a}$ & 10.47 & 0.01 \\
\hline$\triangle N_{1}(\%)$ & 9.83 & 16.59 & -5.48 & 34.83 & 30.40 & 30.24 & 10.67 & 0.06 \\
\hline$\triangle N_{2}(\%)$ & 98.40 & 113.00 & -28.40 & 223.30 & 214.80 & 220.60 & 83.74 & 0.06 \\
\hline$\triangle N_{3}(\%)$ & 108.20 & 129.60 & -33.90 & 258.10 & 245.20 & 250.80 & 94.12 & 0.06 \\
\hline
\end{tabular}

\section{Farmers assessment of the feeding trial}

Among supplemented group farmers prefer treatment 6 , however control group were least selected. This shows that $\mathrm{T}_{6}$ was not only better economically, but also was recognized by farmers as a preference choice. Farmers around Zekolla were impressed with the technology being demonstrated. Because of notable improvement in growth performance, body condition, conformation, libido, locally availability of cowpea hay and health status were the major observations compiled from the respondents. The drawbacks for the feed supplementation raised by farmers were the amount and frequency of feed given to the animal per day is too much that may cause animal health; fattening without castration and younger age of goats may reduce the response to feeding; unavailability of concentrate fed and lack of finance to undertake the technology; high cost and labor intensive; indoor feeding not consider farmer practice. Therefore in agreement with Baltenweck et al. (2020), to make the farmers adopt this feeding practice the cowpea hay preparation method should be available; provision of adequate credit is necessary; extension worker should be committed to popularize the technology specially for pre-urban and urban area in which they have fattening experience; awareness creation through training is essential that long period fattening affect quality of meat and total return from production; fattening at younger age highly preferred by abattoirs and fast growth in lean meat and overall body condition. Strengthening market linkage with abattoir for better market value is essential. The farmer expects a minimum rate of return of $50 \%$ if he/she is to adopt a new practice as compared to the practice he/she used to do. In this experiment, the rate of return was above the recommendation of CIMMYT (1985). However, further evaluation under on farm condition should be done in order to maximize the profit and easy adoption of the technology. 
The present study revealed that there were no significant differences in intake, digestibility, linear body measurement and growth performance of goats fed different proportion of concentrate and cowpea hay. However, sole cowpea hay supplementation performs better in terms of net return and farmers' preference. Therefore, supplementation of sole cowpea hay would be both biologically and economically the optimum level for Abergelle goats bred. Moreover, the result suggests that cowpea hay could replace concentrate mix in goats feeding in which concentrates are not available or expensive for smallholder farmers in the rural area.. Therefore, intervention in disseminating the use of cowpea hay is essential as the forage could be a useful feed in improving the productivity of goat under intensive production system. Verification of the proposed feeding regime under smallholders is essential as well as the performance and economics of length of stay in feedlots should be further study in the future

\section{DECLARATIONS}

\section{Authors' contribution}

All authors contributed equally to this research work. All authors read and approved the final manuscript.

\section{Acknowledgements}

The Authors would like to thank Sekota dry land agricultural research center for their support during data recording and feeding of animal.

\section{Conflict of interests}

The authors declare that we have not conflict of interest. Bewketu Amare and Ayalew Girmay have declared and agree the rule of the journal and put the signatures on the declaration form. Bewketu Amare is first Author whereas Ayalew Girmay is second Author of the papers. The contribution of the Author Bewketu Amare is from initiation of the paper until final write up. But, Ayalew Girmay was contributed for presentation of the paper in regional review.

\section{REFERENCES}

AFRC (Agricultural Food and Research Council) (1993). Energy and protein requirements of ruminants. An advisory manual prepared by the Agricultural Food and Research Council technical committee on responses to nutrients. CAB International, Wallingford, UK, 342pp. https://books.google.com/books/about/Energy_and_Protein_Requirements_of_Rumin.html

Ajebu N, Meseret T and Aster A (2012). Effects of substituting maize with kocho on intake, digestibility, nitrogen utilization and body weight gain in sheep fed a basal diet of Rhodes grass hay. Ethiopian journal of applied Science Technology, 3(2):13-24. http://journals.ju.edu.et/index.php/ejast/article/view/861

Alexander G, Ravi D, Reddy RCh, Saxena KB, Hanson JU, padhyaya HD, Blümmel M. (2007). Forage yield and quality in pigeon pea germplasm lines. An open access Journal .International crop research institute for semi-arid tropics, 3(1) 1-3. http://oar.icrisat.org/id/eprint/2879

AMAREW (Amhara Micro-enterprise development, Agricultural Research, Extension and Watershed Management) (2006). Unpublished. Bahir Dar, Ethiopia, 45pp. https://www.oecd.org/countries/ethiopia/42319183.pdf

AOAC (Association of Official Analytical Chemists) (1995). Animal Feed: Sample preparation (950.02) and Official methods of analysis. 16 ${ }^{\text {th }}$ edition. Association of Analytical Chemists, Viriginia, USA. http://www.aoac.org/techprog/Intro98.htm

ARC (Agricultural Research Council) (1980). The Nutrient Requirements of Ruminant Livestock. CAB International, Wallingford, UK. https://www.amazon.com/Nutrient-Requirements-Ruminant-Livestock-Agricultural/dp/0851986196

Baltenweck I, Cherney D, Duncan A. et al (2020). A scoping review of feed interventions and livelihoods of small-scale livestock keepers. Nature Plants, 6: 1242-1249 https://doi.org/10.1038/s41477-020-00786-w

Baur H, Sissoko K and Debrah S (1989). The economics of peasant cattle fattening in Mali. African Research Network for Agricultural byproducts (ARNAB). Overcoming constraints to the effective utilization of agricultural by-products as animal feed. Proceeding of the fourth annual workshop held at the institutes of animal research, Mankon station, Bameeda, Cameroon, ARNAB, Addis Ababa, Ethiopia, 49-60pp. https://cgspace.cgiar.org/bitstream/handle/10568/50032/Overcoming Constraints.pdf

Bewketu A, Tewoderos A and Likawent $Y$ (2015). Evaluation of body weight change and carcass characteristics of Abergelle and Abergelle $X$ Baka cross $(50 \%)$ goat fed hay supplemented with different level of concentrate mixture. In press: proceedings of the annual regional conference of completed livestock research activities. Amhara regional Agricultural Research institute (ARARI), Bahir Dar, Ethiopia. www.arai.gov.et

CIMMYT (International Maize and Wheat Improvement Center) (1985). From Agronomic Data to Farmers Recommendations. Economics Programme. Mexico. 32pp. http://repository.cimmyt.org/xmlui/bitstream/handle/10883/830/13803.pdf

CSA (Central Statistics Authority, 2014). Report on livestock and livestock characteristics statistics. I(2), Addis Ababa, Ethiopia, 417pp. http://www.csa.gov.et/ehioinfo-internal

De Boer H., Dumont B.L., Pomeroy R.W. and Weninger J.H (1974). Manual on E.A.A.P. reference methods for assessment of carcass characteristics in cattle. Livestock Production Science. 1: 151-164. http://aei.pitt.edu/50083/1/B0053.pdf

Devendra C. and Mcleroy B.G (1982). Goat and sheep production in the tropics. Long man, London and New York, 84pp. http://www.worldcat.org/oclc/8451618

Duncan, D. B (1955). Multiple range and multiple F tests. Biometrics, 11:1-42. http://garfield.library.upenn.edu/classics1977/A1977DM02600001.pdf

Foster JL, Adesogan AT, Carter JN, Blount AR., Myer RO and Phatak SC (2009). Intake, digestibility, and nitrogen retention by sheep supplemented with warm-season legume hays or soybean meal. Journal Animal Science, 87(9):2891-2898 https://doi.org/10.2527/jas.2008-1637

Haddad SG. (2005). Effect of dietary forage: concentrate ratio on growth performance and carcass characteristics of growing Baladi kids. Small Ruminant Research, 57(1): 43-49 https://doi.org/10.1016/j.smallrumres.2004.05.001 
Halima H, Michael B, Barbara R and Markos T (2012). Phenotypic characterization of Ethiopian indigenous goat populations. African Journal of Biotechnology, 11(73), 13838-13846, https://doi.org/10.5897/AJB12.2092

Hasan M.R., Akbar M.A., Khandaker Z.H. and Rahman M.M (2010). Effect of nitrogen fertilizer on yield contributing character, biomass yield and nutritive value of cowpea forage. Bangladesh Journal of Animal Science, 39(1\&2): 83 - 88. https://doi.org/10.3329/bjas.v39i1-2.9680

Jemberu D, Solomon M, Firew T, and Kurt J (2010). Effect of supplementation of Simada sheep with graded levels of concentrate, mix on feed intake, digestibility and live weight parameters. Tropical Animal Health Production, 42(5):841-848. https://doi.org/10.1007/s11250-009-9496-3

Karachi $M$ and Zengo $M$ (1998). Legume forages from pigeon pea, leucaena and sesbania as supplements to natural pastures for goat production in western Tanzania Agro forest System,39: 13-21. https://doi.org/10.1023/A:1005859617603

Kearl LC (1982). Nutrient requirements of ruminants in developing countries. International feed stuff Institute, Uttah, USA, 120pp. https://digitalcommons.usu.edu/etd/4183

Keba F (2009). Sheep production system in Damot Gale Woreda and supplementary value of pigeon pea (Cajanus cajan) and sweet potato root (Ipomoea batatus) in sheep fattening diets. Master of scienceThesis, Hawassa University, Ethiopia.

Lee R (2008). Ruminant nutrition for glaziers. ATTRA national sustainable agricultural information service. www.attra.ncat.org, 7-15pp.

McDonald R.E., Edward R.A., Greenhalgh J.F.D. and Morgan G.A (2002). Animal nutrition. 6 ${ }^{\text {th }}$ edition. Pearson Educational Limited. Edinburgh, Great Britain, 544pp, ISBN13: 9780582419063; ISBN10: 0582419069, https://m.barnesandnoble.com/w/animalnutrition-peter-mcdonald/1100484409

Mekuriaw Y, and Asmare B (2018). Nutrient intake, digestibility and growth performance of Washera lambs fed natural pasture hay supplemented with graded levels of Ficus thonningii(Chibha) leaves as replacement for concentrate mixture. Agriculture \& Food Security, 7:30. Doi: https://doi.org/10.1186/s40066-018-0182-4

Ndemanisho, EE, Mtenga, LA, Kimbi, EFC, Kimambo, AE, Mtengeti, EJ (1998). Substitution of dry Leucaena leucocephala (DLL) leaves for cotton seed cake (CSC)as a protein supplement to urea treated maize stover fed to dairy weaner goats. Animal Feed Science Technology, 73(3-4): 365-374. https://doi.org/10.1016/S0377-8401(98)00139-4

Owolabi AO, Ndidi US, James UD, and Amune FA (2012). Proximate, Antinutrient and Mineral Composition of Five Varieties (Improved and Local) of Cowpea, Vigna unguiculata, Commonly Consumed in Samaru Community, Zaria-Nigeria. Asian Journal of Food Science and Technology, 4:70-72. 4(2):70-72 .ISSN: 2042-4876.

Patra AK, Sharma K, Dutta N and Pattanaik AK (2006). Effect of partial replacement of dietary protein by a leaf mixture on nutrient utilization by goats in pre-and late gestation. Small Ruminant Research, 63(1-2): 66-74. https://doi.org/10.1016/j.smallrumres.2005.02.008

Paul BK, Groot JC, Maass BL, Notenbaert AM, Herrero M, Tittonell PA (2020). Improved feeding and forages at a crossroads: Farming systems approaches for sustainable livestock development in East Africa. Outlook on Agriculture, 49(1): 13-20. doi: https://doi.org/10.1177\%2F0030727020906170

SAS (Statistical Analysis System) (2003). Statistical Analysis System Institute, Inc.cary, NC. Science. Uppsala, Sweden.

SDARC (Sekota dry land agriculture research center) (2013). Annual report of research center in 2013.

Tesfa G, Tegene N, Girma A and Arth L. G (2013). Effect of supplementing grazing Arsi-Bale sheep with molasses-urea feed block on weight gain and economic return under farmers' management condition. Journal of Cell and Animal Biology, 7(10):125-131. https://doi.org/10.5897/JCAB11.030

Upton M (1979). Farm management in Africa: The principle of production and planning. Oxford University press, UK. 282-298pp. https://www.abebooks.co.uk/products/isbn/9780192156464/30743147345

USAID (United States Agency for International Development of the United States Government) (2013). Agricultural Growth Project Livestock Market Development. Value chain analysis for Ethiopia. USAID bulletin, 150pp. https://www.usaid.gov/sites/default/files/documents/1860/AGP-LMD

Van Soest PJ, and Robertson BJ (1985). Analysis of forage and fibrous food. A laboratory manual for animal science 613. Cornell University, Ithaca, New York, USA. http://www.worldcat.org/oclc/223471931

Wamatu J, Alkhtib A, and Gardi M (2019). Leveraging traditional crops for food and feed: a case of hulless barley (hordeum vulgare) landraces in Ethiopia. Journal of Experimental Biology and Agricultural Sciences 7(1):42-50. http://dx.doi.org/10.18006/2019.7(1).42.50

WZAD (Waghimra Zone Agricultural Department Office) (1995). Waghimra Zone Baseline Data. 65pp. https://en.m.wikipedia.org/wiki/Wag Hemra Zone

Yihalem D, Berhan T and Solomon M (2004). Effect of harvesting date on composition and yield of natural pasture in northwestern. Ethiopia Tropical Science, 45(1):19-22. https://doi.org/10.1002/ts.40 